\title{
The New Role of University English Language Teachers under New Social Circumstances
}

\author{
Fengjie ZHAI \\ Tianjin University of Technology and Education, Tianjin 300222, China
}

\begin{abstract}
There is no doubt about the importance of English language as a compulsory course in universities in reaction to the market and social necessities. It is notable however, that the subject has come across three main challenges, which have necessitated teachers to transform their roles.
\end{abstract}

KEYWORD: University English Language Teachers; Challenges; Role Transformation

\section{INTRODUCTION}

The progress of globalization has highlighted the importance of English language as the one of the main media of communication in the global market. The English language is considered the world over as a paramount mode of communication. Brock states general education aims at "building personal subjectivity and forming inter-subjective relationship with objective circumstances. It is non-professional and non-profitable education on basic knowledge, skill and attitude in a broad sense".

General education targets at cultivating qualified "citizen" and "whole-person" accorded to modern standards, at fostering students' cultural and educational attainment to rationalize their knowledge structure, at training their basic abilities to all-round capabilities, and at developing refined interest and building perfect personality in order to achieve an excellent humanity (Zhang and Xu, 2008). Therefore, the ultimate aim of university English language teaching and learning is to help students master a language, understand different cultures, promote self-discipline and develop selfperfection. However, the achievement of these goals remains questionable.

\section{THREE MAIN CHALLENGES FACED BY UNIVERSITY ENGLISH LANGUAGE TEACHING AND LEARNING}

There has been a major benefit from the development of Internet, post 90s university students have a wide range of information, and have a strong dependence on electronic products. They can acquire knowledge quickly via various means, for instance, books, English programs, English movies, Internet and so on. Therefore, university English language teachers must recognize that they are no longer the key means for students to acquire information. Rather, students can get access to the needed information quickly by themselves.

Since most post 90s university students are the only child in their families, parents tend to encourage them more, and to have a higher expectation on them because of the influence of the new educational concept. Students are versatile, selfconfident, and are willing to show their advantages over others. These students have put forward new challenges for teachers regarding the classroom teaching methods.

Due to the differences on university entrance exams, teaching methods in high schools, teaching contents and individual diversities among regions, the English language capabilities of university students are not standardized. It is also a challenge for university English language teaching and learning to make all the students progress from their original basis.

\section{SUGGESTIONS CONCERNING UNIVERSITY ENGLISH LANGUAGE TEACHING AND LEARNING}

It is essential for university English language teachers to constantly improve their self-quality, to keep paces with times in order to attract students' attention by their extensive knowledge and honorable personality when facing post 90 s students characterized by the wide range of knowledge and the quick access to information. Professional knowledge, teaching organizational capability and 
teaching methods will directly have an effect on post 90s students' learning attitude. It is with professional competence and moral integrity that teachers can win the esteem from their students. It is also necessary for teachers to understand the characteristic of post $90 \mathrm{~s}$ students so as to narrow the emotional "gap", to think from their perspectives, and to sincerely give a hand to resolve their problems. Thus, teachers and students can get closer to be friends. Students can be greatly encouraged by trusting their teachers.

Motivation is the best teacher. The key element of learning improvement is to inform students of the importance of English language in their life and work in order to inspire their learning enthusiasm and to switch active learning from negative learning. Self-learning will promote aptitude, autonomy, pleasure, effectiveness and higher uptake, and will be more suitable for new circumstances (Oxford, 1999). The roles of teachers are participant, guidance and consultant in the progress of assisting students to learn English language. Therefore, it is critical to understand the requirement of post 90s students in order to inspire their English language learning autonomy, and to realize the active learning continuity.

Students should be the center of university English language teaching. It is vital to affirm their advantages, and to give them a relative freedom of creativity and autonomy. Teachers should change the traditional "spoon-feed" teaching methods into developmental discussion mode to get students actively involved. Through the guidance of questions and answers, it will drive students to think and to mobilize their learning enthusiasm. By this means it can create a free and easy classroom learning environment for students to put forward their opinions and to enhance their creativity (J.S. Brock, 2001). In classroom teaching, it is important to apply multi-media teaching method to show the utility of English to students with the aim of attention attraction and learning interest. For instance, in order to lead students to have a better understanding of sentences or vocabulary, teachers can not only make use of sample sentences for reference, but can apply language situation in some videos that they are interested in. It is suggested that the video materials are the ones which students are familiar with. In addition, brainstorming discussion concerning contemporary social issues can be also carried out in classroom to expand thinking and language capability.

It needs to be noted that teachers should keep their information updated during their course. Language has been updated with times. There are new words coming up, and the meaning of the same words keeps increasing. Consequently, English language teaching should be newly informed, and should match the English terms with modern
Chinese language. It is also advised to embody Internet glossary in the progress of teaching and learning for a better understanding and language application.

Currently, most university English language teaching is carried out by group classes. Compared to small-scale teaching, group teaching might lead to less communication and interaction between teachers and students. Since the close emotional relationship is beneficial for learning activity improvement, teachers can make up the gap by assignments and exam papers to make up emotion absence. In other words, teachers should take each piece of assignment and exam paper serious to make students feel that they have been fully paid attention to, and that they have the emotional relations with the teacher individually. There is a common phenomenon that students will have a sense of achievement when they are praised because of their assignment or exam progress. As a result, students will have more interest in English language learning, and will have a closer relation with the teachers. Thus, the teacher should offer positive feedback on their success or effort. Concerning those who are less capable on learning, teachers should help them to discover their problems and to find out the root, hence, the given suggestions will provide guidance for them. It is important to provide opportunities for students to show their learning process, to build the consciousness of self-learning and self-discipline, and to improve language learning confidence (Brown, 1987).

The acquisition of knowledge and skill will differ by intelligence and capability diversity. In learning process, students may have different levels of understanding the same explanation. As a consequence, the learning interest levels are various (Zhang, 2011). Besides, university English language learning is a further improvement based on previous learning. Due to the differences of teaching and learning requirements, teaching standards, individual cognitive abilities, learning habits and other causes, the English language competences are individually different, which calls for them to understand their own levels, to recognize their advantages and disadvantages under the guidance of teachers. It is also the responsibility of the teacher to guide students to have a comprehensive cognition and evaluation over themselves, and to propose well targeted learning instruction according to individual diversity by setting various difficulties and quantities assignments to achieve English language improvement. In the meantime, it is significantly important to focus on instructing students' selfdiscipline, the abilities to discover problems and resolution by themselves.

After classes, teachers can also strengthen the communication with students via Internet to offer necessary support, to lead them to active 
participation in class, and to enlighten their creative thinking. All these methods can form a good and interactive learning atmosphere, not only have the function of checking class attendance, but also cultivate students with their capability to solve practical problems. Additionally, teachers can have an overall understanding of to what degree do students acquire knowledge in class. Thereby, teachers can fill learning gaps, adjust teaching paces, and improve teaching methods.

\section{CONCLUSION}

The success of learning a second language greatly depends on the interest and investment of time and effort put by the learner (Brown, 1987). Under the background of highly developed information era, it is essential to keep updated, to improve professional knowledge and to recognize the changing role for university English language teachers. Through teaching methods adjustment, teachers should attempt to inspire learning interest for students and make them realize the importance of English in their life and work. Meanwhile, English language teachers should attract students' attention and admiration by marketing and communication in order to encourage their participation.

\section{REFERENCES}

[1] Brock, J.S. 2001, On the Philosophy of Higher Education. Hangzhou: Zhe Jiang Education Publishing House.

[2] Brown, H. D. 1987. Principles of Language Learning and Teaching. New Jersey: Prentice Hall.

[3] Oxford, R. L. 1990. Language Learning Strategies: What Every Teacher Should Know. Newbury House: Rowley, Mass.

[4] Zhang, D.J. 2011.Educational Psychology. Beijing: People's Education Press. 